\title{
A Promising Practicum Pilot - Exploring Associate Teachers' Access and Interactions with a Web-based Learning Tool
}

\author{
Diana Petrarca \\ University of Ontario Institute of Technology, \\ Oshawa, Ontario, Canada \\ diana.petrarca@uoit.ca
}

\begin{abstract}
This paper explores how a small group of associate teachers (i.e., the classroom teachers who host, supervise, and mentor teacher candidates during practicum placements) accessed and interacted with the Associate Teacher Learning Tool (ATLT), a web-based learning tool created specifically for this new group of users. The ATLT is grounded in web-based learning and discipline-specific research and conceptualized within a framework of reflective practice and constructivist learning theory. The ATLT was created specifically for associate teachers, as an affordable and flexible alternative method of providing support for these critical community members who partner with the Faculty of Education at the University of Ontario Institute of Technology (UOIT), a university in the Greater Toronto Area in Ontario, Canada. Through analysis of associate teachers' usage patterns and emerging themes via the ATLT's internal tracking system, the findings of this work revealed that although associate teachers accessed and interacted with the ATLT in diverse ways, several commonalities emerged. The findings of this exploratory work suggest that continued and expanded implementation and research of using a web-based form of learning that is grounded within a body of research, is warranted.
\end{abstract}

Keywords: associate teachers, practicum, web-based learning tools, professional development, reflection, pre-service teacher education programs

\section{Introduction}

\section{Field Experience / Practicum in Pre-service Teacher Education}

An essential element of pre-service teacher education programs includes the practicum or field experience (Allen, 2003; Beck \& Kosnik, 2000; Crocker \& Dibbon, 2008; Darling-Hammond, 2006; Wideen \& Holborn, 1990; Wilson, Floden, \& Ferrini-Mundy, 2001), which in this paper

Material published as part of this journal, either on-line or in print, is copyrighted by the publisher of the Journal of Information Technology Education. Permission to make digital or paper copy of part or all of these works for personal or classroom use is granted without fee provided that the copies are not made or distributed for profit or commercial advantage AND that copies 1) bear this notice in full and 2) give the full citation on the first page. It is permissible to abstract these works so long as credit is given. To copy in all other cases or to republish or to post on a server or to redistribute to lists requires specific permission and payment of a fee. Contact Editor@JITE.org to request redistribution permission. refers to the in-class teaching experience where teacher candidates (i.e., pre-service teacher education program students) have opportunities to observe and teach in classrooms. The practicum component of a pre-service teacher education program, ideally reflects the program's overarching philosophies and goals, guides the implementation of the field experience as well as the role of the associate 
teacher; however, communication of program philosophies and goals does not always occur (Darling-Hammond, Hammerness, Grossman, Rust, \& Shulman, 2005).

There exist many discrepancies in practicum experiences within and among pre-service teacher education programs, however, one commonality shared by exemplary pre-service teacher education programs included "strong relationships between universities and schools that share standards of good teaching consistent across courses and clinical work" (Darling-Hammond \& Baratz-Snowden, 2007, p. 120). Darling-Hammond and Baratz-Snowden (2007) concluded that effective practicum programs included clear and explicit goals regarding teacher candidates' practice; associate teachers who modeled sound practice; regular teaching opportunities for teacher candidates, with ongoing feedback and guidance from the associate teacher; regular opportunities for the teacher candidate to apply theory to practice; a gradual increase of teacher candidate responsibility in all areas of classroom practice; and regular and structured opportunities for teacher candidate reflection on classroom practice.

\section{The Associate Teacher - A Critical Role}

The associate teacher, the classroom teacher who hosts, supervises, and works with the teacher candidate on a daily basis during the field experience, plays a fundamental role in the teacher candidate's growth and development as a teacher (Allen, 2003; Beck \& Kosnik, 2000; Crocker \& Dibbon, 2008; Darling-Hammond, 2006; Wideen \& Holborn, 1990; Wilson et al., 2001). The importance, diversity, and multifaceted nature of the associate teacher role becomes even more pronounced given the complexities of maintaining an effective practicum as just previously described. Darling-Hammond et al. (2005) summarized the multifaceted role of the associate teachers, describing the ideal field experience for teacher candidates. They maintained that:

..typically, the ideal has been a placement in which student teachers are supported by purposeful coaching from an expert cooperating teacher in the same teaching field who offers modeling, co-planning, frequent feedback, repeated opportunities to practice, and reflection upon practice while the student teacher gradually takes on more responsibility. (p. 409)

\section{A Problem with Practicum}

The associate teacher plays an important role in the teacher candidate's growth and development as a teacher, yet there still exists a lack of support, collaboration, and training to assist the associate teacher in this influential role (Allen, 2003; American Federation of Teachers [AFT], 2000; Hobson, 2002; Levine, 2006; National Commission on Teaching and America's Future [NCTAF], 1996; Sanders, Dowson, \& Sinclair, 2005). The recommendation for increased or additional associate teacher supports to assist them in implementing this critical role resonates throughout the field experience and associate teacher literature (Beck \& Kosnik, 2000; Borko \& Mayfield, 1995; Duquette, 1998; Kahn, 2001; Levine, 2006; Ramanathan \& Wilkins-Canter, 1997; Rippon \& Martin, 2006; Sanders, 2005; Volante, 2006). When associate teachers received support and/or training to carry out the role via courses, workshops, coaching programs, or other derivations of support related to the supervision of teacher candidates, teacher candidates experienced more positive learning experiences (Coulon, 2000; Giebelhaus \& Bowman, 2002; Kent, 2001; McIntyre \& Killian, 1987), compared to teacher candidates who worked with associate teachers who did not participate in training programs. Associate teachers and teacher candidates indicated a need for training and supports (Borko \& Mayfield, 1995), typically on an as needed basis (Kent, 2001; Ramanathan \& Wilkins-Canter, 1997); however, lack of time, lack of remuneration, attitudes, willingness, and beliefs prevent such training from occurring (Kent, 2001; Ramanathan \& Wilkins-Canter, 1997). 


\section{Addressing the Problem}

Suggestions to improve how classroom teachers implement this critical role included the need for associate teachers to observe more and offer feedback (Borko \& Mayfield, 1995), encourage reflection, provide support and guidance regarding how to connect theory and practice (Beck \& Kosnik, 2000; Borko \& Mayfield, 1995), collaborate, establish more personal connections, offer more emotional support, and allow their teacher candidates increased opportunities to observe (Beck \& Kosnik, 2000). Beck and Kosnik (2000) also suggested that pre-service programs increase collaboration and communication with associate teachers and provide increased acknowledgement and appreciation to recognize the critical work that they do. Similarly, in their examination of teacher education programs, the AFT's Teacher Education Task Force (AFT, 2000), found several troubling issues with the field experience, including a general lack of incentives, supports, and training for associate teachers, explaining, "there frequently is far too little coordination among university faculty, clinical supervisors and cooperating teachers regarding standards of good teaching and the requirements of a rigorous clinical experience" (p. 28).

It has also been suggested that pre-service teacher education programs should avoid prescribing narrow and rigid measures to implement the associate teacher role, but rather pre-service teacher education program should expose the associate teachers to a variety of approaches in implementing the role (Beck \& Kosnik, 2002; Weasmer \& Woods, 2003). Given the complexity of the associate teacher role and the diverse circumstances that surround individual practicum placements, a variety of approaches provided in a non-prescriptive fashion may provide these teachers with concepts to support them in their indeterminate zones of practice (Schön, 1987) as associate teachers.

\section{Purpose of Paper}

In response to this challenge, this paper explores how a unique group of users (i.e., associate teachers) accessed and interacted with the Associate Teacher Learning Tool (ATLT), a webbased learning tool developed specifically for associate teachers, as an alternative approach in providing associate teachers with professional development opportunities. This paper's purpose is exploratory in nature, given that to the best of the author's knowledge, at the time of the ATLT's inception, no web-based learning tool grounded in associate teacher, field experience, and web-based learning tool literature was available. A review of the learning object repositories and consultation with experts in the field of teacher education learning and web-based learning tools, suggested further that no such web-based learning tool existed for this new audience (i.e., associate teachers). This paper explores how one pre-service teacher education program piloted a web-based learning tool to provide those teachers who host, supervise, and work with the students on a daily basis in the field, with professional learning opportunities. Specifically, this paper explores how associate teachers accessed and interacted with the ATLT (i.e., dates/times of use, pages accessed, length of time on pages, and interaction with activities).

The first section of this paper reviews the literature that is relevant to this study and the ATLT. The sections that follow describe the mixed-methods methodology, including data collection and analysis. Next, the paper presents findings emerging from this exploratory study, as well as a discussion of the findings and the implications for practice and future research.

\section{Theoretical Context}

\section{Constructivist Learning}

Constructivist theories vary in number, definitions, and orientations, at times holding opposing positions within the "constructivist" domain (Fosnot, 2005; Phillips \& Soltis, 2004; Phye, 1997). 
Jonassen, Hernanadez-Serrano, and Choi (2000) described constructivism as a fusion of numerous theories of learning including "socially shared cognition, situated learning, everyday cognition and everyday reasoning, activity theory, ecological psychology, distributed cognition, casebased reasoning, and Deweyian pragmatism" (p. 107). They explained that the constructivist learning perspective views the individual as a "natural learner" (p. 107) where "we naturally work to make sense of experiences based on prior experience and knowledge and use that newly constructed knowledge to generalize to new experiences" (p. 107). The constructivist perspective views learning not as a passive process of receiving or transmitting knowledge, but rather an active process of meaning making by the individual, affected also by social influences, and community beliefs and values (Jonassen et al., 2000). "Constructivists, believe that meaning making (i.e., meaningful learning) involves willful, intentional, active, conscious, constructive practice that includes reciprocal intention-action - reflection cycles. Intentionality, activity, and reflection are essential to meaningful learning, especially in complex and new domains" (Jonassen et al., 2000, p. 111).

\section{Reflection}

In his seminal work, How We Think, Dewey (1933) described reflective thinking as an active, problem-solving process, distinguishing it from "thinking" in that thinking "signifies everything that, as we say, is 'in our heads' or that 'goes through our minds."' (p.2), whereas reflective thought, denotes a more active and problem-solving role of the thinker. Dewey defined reflective thinking as "active, persistent, and careful consideration of any belief or supposed form of knowledge in the light of the grounds that support it and the further conclusions to which it tends" (p.6).

Influenced by Dewey (1916, 1933), Schön (1987) believed that when practitioners faced unique problematic situations, that lie outside the realm of technical rationality, two options exist. The practitioner could either ignore the unique situation/problem or consider the unique situation in a reflective manner. Schön (1987) believed that such reflective practices are fundamental to the acquisition and development of artistry that guides professional practitioners such as architects, counselors, or teachers through indeterminate zones of practice.

\section{Web-based Learning Tools}

Given the abundance of literature regarding learning objects, there remains a lack of consistency and consensus for a unified definition (Downes, 2004; McGreal, 2004; Wiley, 2000), and as such, Kay, Knaack, and Petrarca (2009) altered the Kay and Knaack (2005) terminology by replacing the term learning object for web-based learning tool (WBLT). This paper, then will refer to previously named "learning objects" as WBLTs, and adopts the WBLT term to describe "reusable, interactive web-based tools that support the learning of specific concepts by enhancing, amplifying, and guiding the cognitive processes of learners (Agostinho, Bennett, Lockyer, \& Harper, 2004; Butson, 2003; McGreal, 2004; Parrish, 2004; Wiley, et al. 2004)" (Kay \& Knaack, 2005, p. 231). WBLTs are also cost-effective, accessible, flexible, learner driven, and promote learning (Ally, 2004b; Downes, 2004; Kay \& Knaack, 2005; McGreal, 2004; Wiley, 2000). This paper also refers to learning objects addressed in previous studies as WBLTs.

Although, behaviourist, cognitive, and constructivist learning theory can all be applied to the development of web-based learning tools (Ally, 2004b; Spector, 2000), online learning environments that reflect constructivist learning principles strive to contextualize the learning within a real-world framework (Anderson \& Elloumi, 2004) by providing ATLT users with opportunities to participate in activities that allow for practical application of knowledge (Ally, 2004b). Ally (2004b) affirmed that "learners should be able to interact within their context to personalize information and construct their own meaning" (p. 24), recommending that web-based learning tools contain a variety of interactive components to promote learning. Ally (2004b) further emphasized 
that since learners bring a variety of perspectives and backgrounds to the web-based learning environment, they need to be given control of their learning, have opportunities to construct their own knowledge, collaborate with other learners, actively engage in activities that promote "highlevel processing" (p. 17), and reflection throughout the learning process.

A few examples of technological tools that enhance the construction of knowledge include technologies that promote interaction, demonstrations, simulations, feedback, reflection, case/project/problem based activities, or visualizing through use of video (Jonassen et al., 2000). A WBLT is just an object with content, if careful consideration to the instructional components in its development is ignored (Ally, 2004a; McGreal, 2004; Wiley, 2000). "Instructional design theory, or instructional strategies and criteria for their application, must play a large role in the application of learning objects if they are to succeed in facilitating learning" (Wiley, 2000, p. 9).

\section{Technology Acceptance Model}

The best efforts to create a web-based learning tool grounded in research based content and theoretical constructs might yield little learning, if associate teachers are unwilling to access and interact with the ATLT. As previously explained, oftentimes, lack of time, lack of remuneration, attitudes, willingness, and beliefs prevent associate teacher training from occurring (Kent, 2001; Ramanathan \& Wilkins-Canter, 1997). If these issues are prominent in the field experience, using non-technological based strategies to provide training and supports, it might also be prudent to consider factors that might prevent or enhance associate teacher acceptance and usage of a new technology such as the ATLT.

There are many models described in the literature that examine users' acceptance of new technologies (Venkatesh, Morris, Davis, \& Davis, 2003), however, one of the most widely cited, and empirically backed models, is the Technology Acceptance Model (TAM) (Chuttur, 2009; Venkatesh \& Bala, 2008). Although many derivatives of the Technology Acceptance Model exist, the core constructs of TAM, center on the model's proposition that two key beliefs, perceived usefulness and perceived ease of use; influence the user's acceptance and use of a new technology (Chuttur, 2009; Venkatesh \& Bala, 2008).

Perceived usefulness refers to "the degree to which a person believes that using a particular system would enhance his or her job performance" (Davis, 1989, p. 320), whereas perceived ease of use refers to "the degree to which a person believes that using a particular system would be free of effort" (Davis, 1989, p. 320). Subsequent TAM 2 (Venkatesh \& Davis, 2000) and TAM 3 models (Venkatesh \& Bala, 2008) build on TAM's core constructs but include other constructs such as social influence processes and cognitive processes (Venkatesh and Davis, 2000), and the role of experience and its moderating influence on perceived ease of use (Venkatesh \& Bala 2008).

While, this paper does not measure the associate teachers' acceptance and use of the ATLT, the key elements of TAM might serve as interesting lenses through which to view/consider this study's findings and future areas of research, with respect to associate teachers' access and use of web-based learning tools such as the ATLT.

\section{The Associate Teacher Learning Tool}

The ATLT piloted in this work represented the synthesis and merging of associate teacher, field experience, and web-based learning tool literature grounded in a theoretical framework of reflective practice and constructivist learning. Within this framework, the ATLT, therefore, honored and considered associate teachers' pre-existing personal models of the role of the associate teacher, the teacher candidate, and field experiences in general as critical components in the construction of knowledge. Based on the theoretical constructs that guided this work, the ATLT needed to 
challenge and encourage associate teachers to examine and reflect on their own beliefs and practices as teachers and associate teachers, to engage them in relevant problem solving situations, and to enhance and/or promote the construction of representations or schemas of the AT role and related responsibilities.

The final ATLT piloted in this research consisted of 49 Flash-based pages, accessible via a password protected URL, and organized around five key themes that emerged from the literature: 1) the associate teacher role; 2) getting prepared; 3) planning; 4) feedback; and 5) praxis.

Within the five key modules, the ATLT provided associate teachers with opportunities to learn about the critical associate teacher role, as well as how they might support teacher candidates. The learning opportunities occurred via a variety of presentation formats including:

- Text-based documentation;

- Graphics;

- Video clips (i.e., vignettes of common problems, testimonials, informational, procedural);

- Interactive activities (i.e., self-check activities such as drag-and-drop, select response, roll-overs); and

- Reflective activities (i.e., embedded questions encouraging associate teachers to respond to video case studies, contributing ideas and suggestions, comparing and contrasting, sharing ideas with others on external wiki discussion board).

The ATLT's Flash-based and password protected website also incorporated database software, MySQL. This allowed for the learning tool to track users' times of use, pages visited, frequencies, and text data if user choses to interact with open-ended activities. Figures 1 through 4 provide screen shots of various pages within the ATLT.

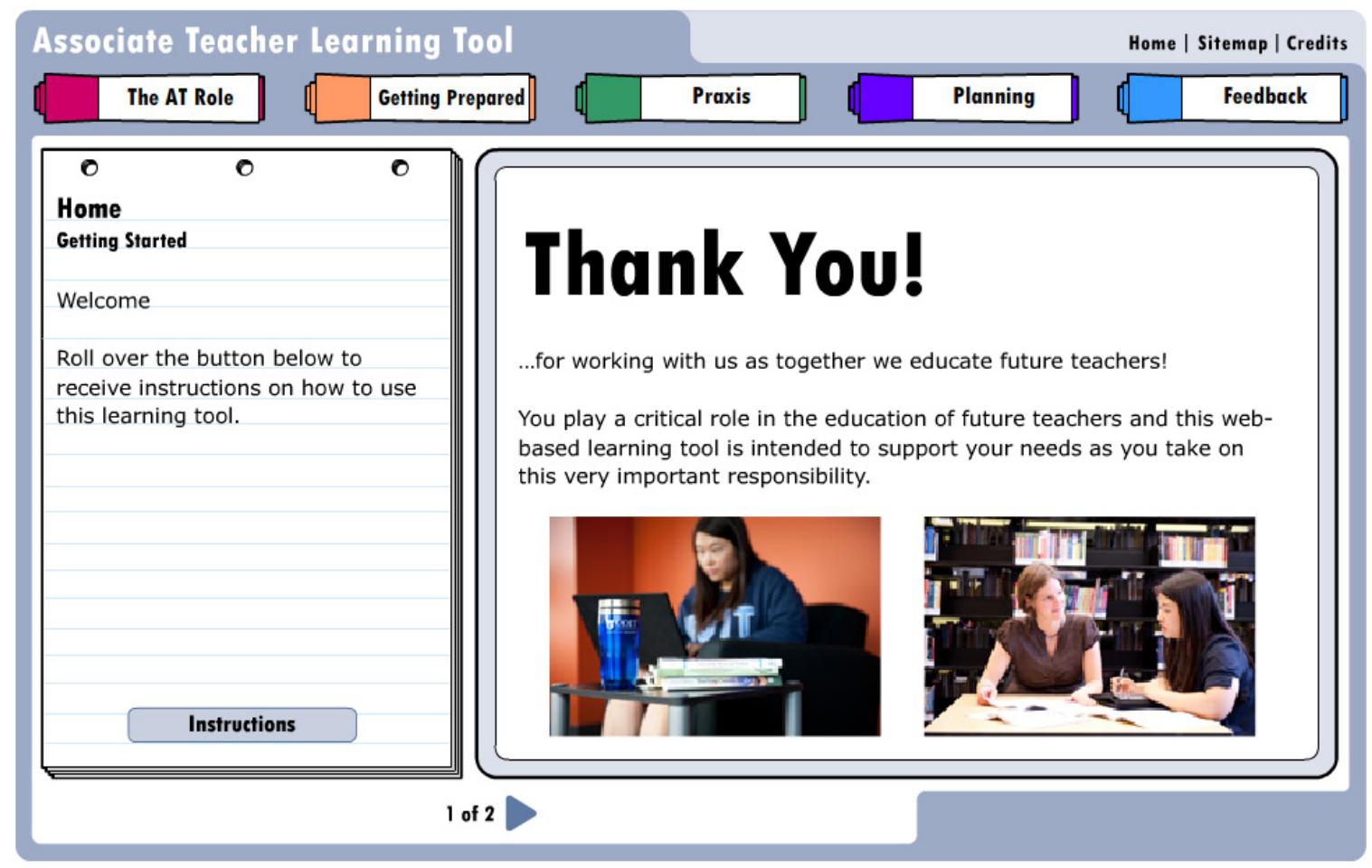

Figure 1: Example of basic layout 


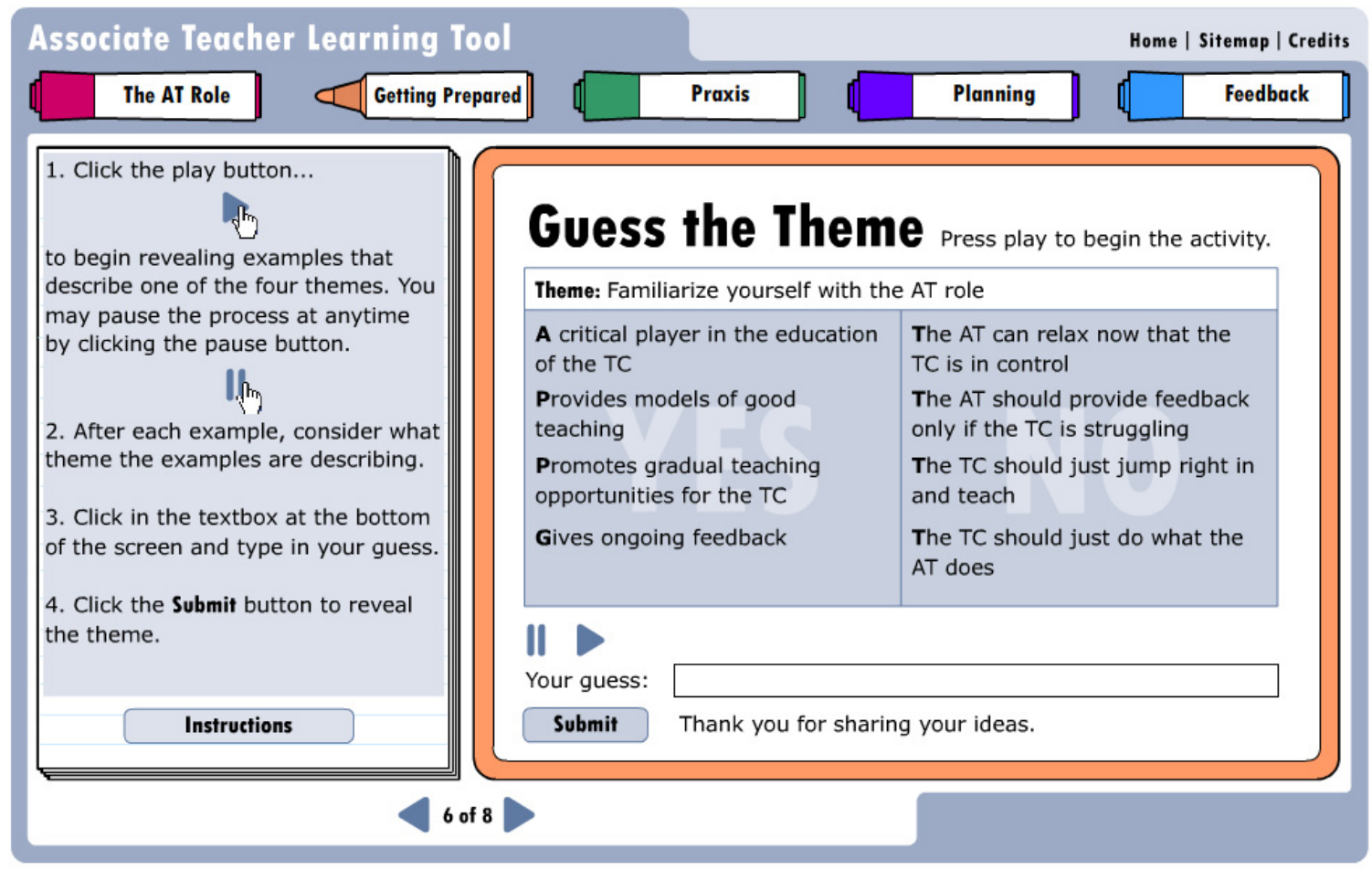

Figure 2: Example of procedural video

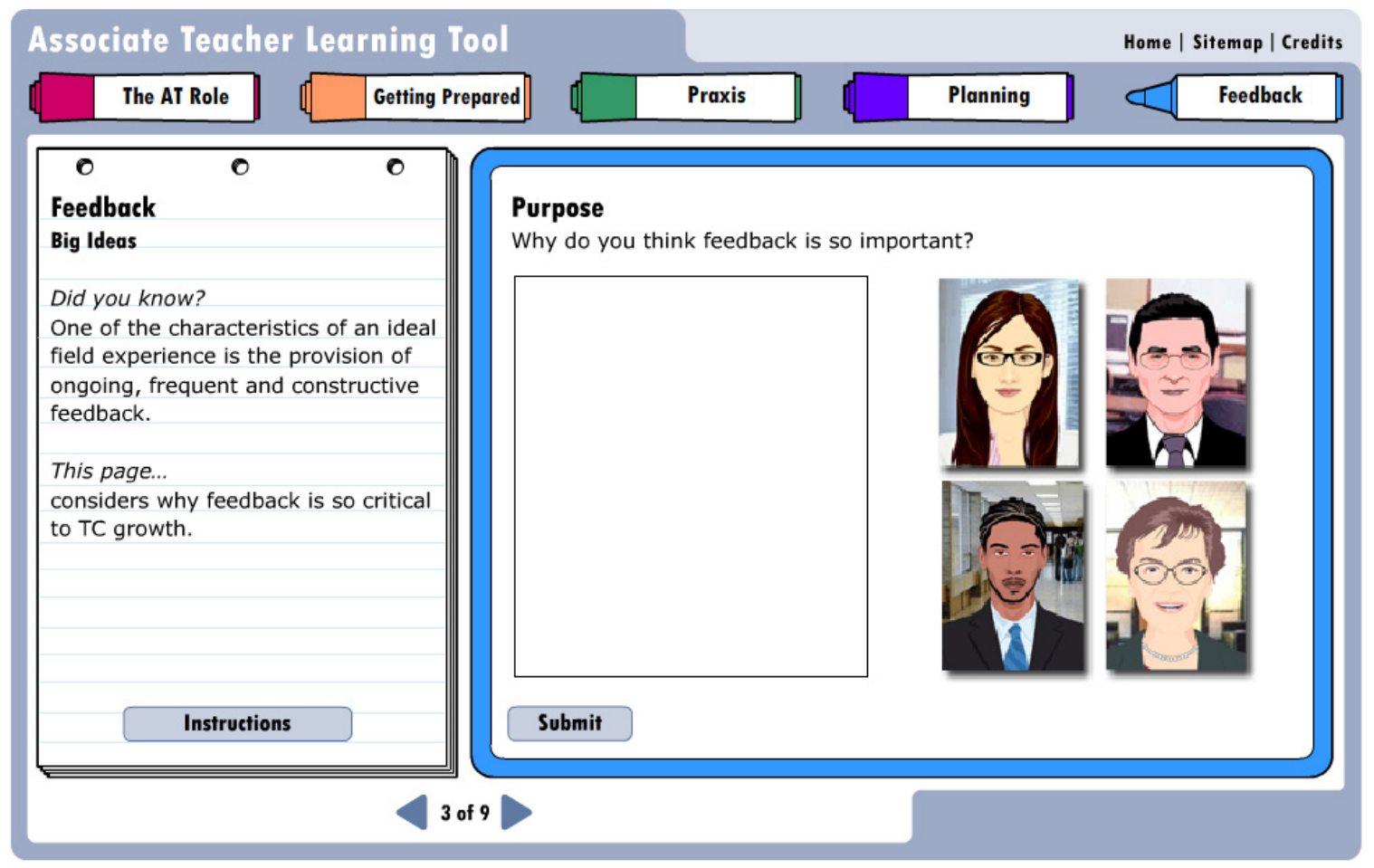

Figure 3: Example of reflective text input 


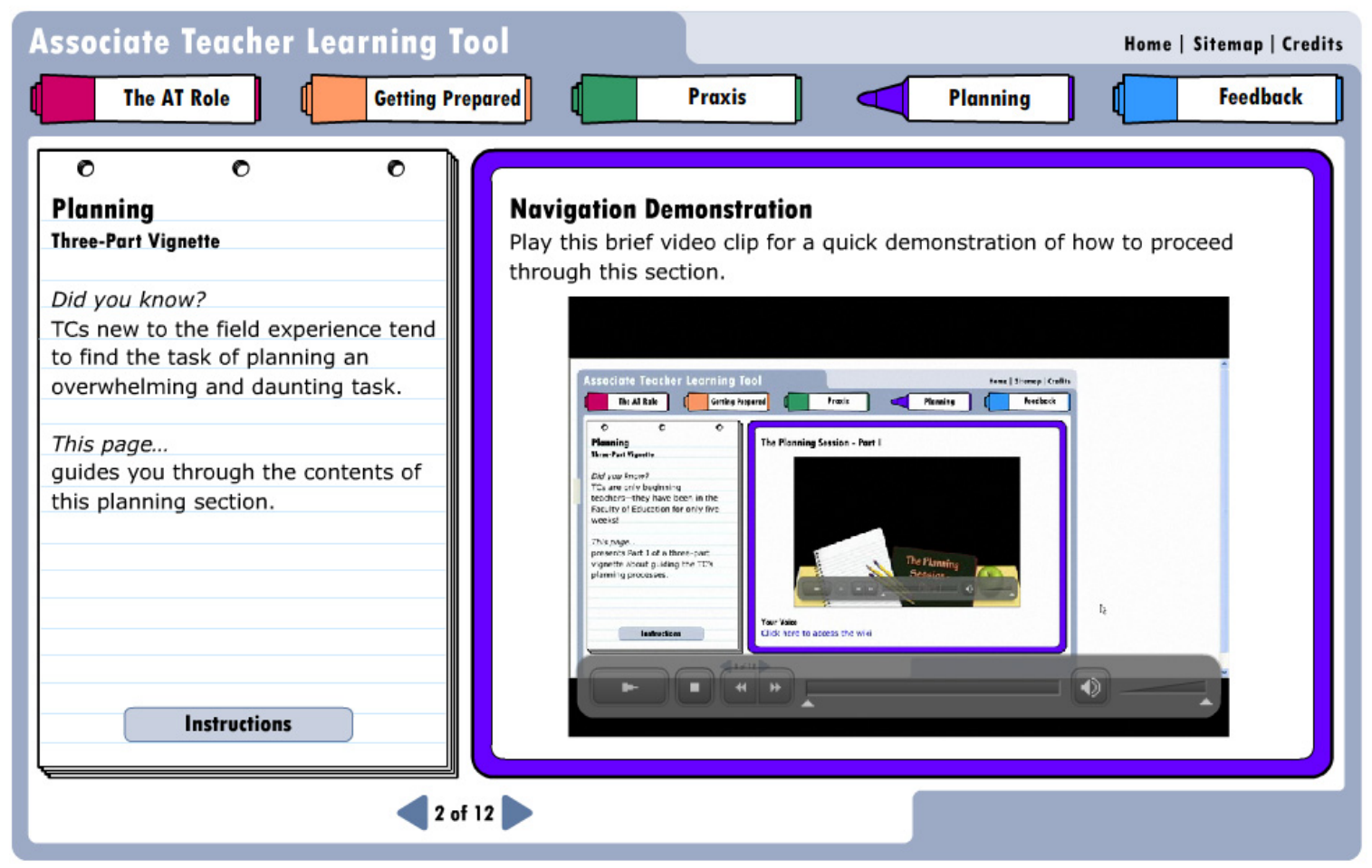

Figure 4: Example of interactivity

\section{Research Methodology}

\section{Mixed Methods Research Methodology}

This study incorporated a mixed methods "alternative" where "the researcher mixes or combines quantitative and qualitative techniques, methods, approaches, concepts or language into a single study" (Johnson \& Onwuegbuzie, 2004, p. 17). Teddlie and Tashakkori, (2009) described mixed methods research as "an alternative to the dichotomy of qualitative and quantitative traditions" (p. 4), distinguishing qualitative data from quantitative data in that quantitative data collection strategies result in numeric data for statistical analysis and qualitative data collection strategies result in narrative data for thematic analysis. Quantitative and qualitative methods are both valuable research approaches, and while one method is not better than the other (Creswell, 2003; Neuman, 2003), the blending of quantitative and qualitative methods provides a wider framework for the research and allows for more effective and fuller approaches to social science research (Creswell, 2003; Johnson \& Onwuegbuzie, 2004). "The goal of mixed methods research is not to replace either of these approaches but rather to draw from the strengths and minimize the weaknesses of both in single research studies and across studies" (Johnson \& Onwuegbuzie, 2004, p. 14).

Exploratory questions tend to "generate information about unknown aspects of a phenomenon" (Teddlie \& Tashakkori, 2009, p. 33) and typically emphasize qualitative data (Teddlie \& Tashakkori, 2009). The nature of the inquiry guiding this research design, however, focused on both quantitative and qualitative data. Using the exploratory (Teddlie \& Tashakkori, 2009; Yin, 2003) nature of the study as a guide (Creswell, 2003; Teddlie \& Tashakkori, 2009; Yin, 2003), quantitative and qualitative types of data collection and analysis occurred, drawing upon the mixed methods design families from Teddlie and Tashakkori's (2009, p. 145) "Methods-Strands Matrix: A Typology of Research Designs Featuring Mixed Methods", allowing for a fuller and more comprehensive study (Neuman, 2003). 


\section{Participants}

This study occurred in a pre-service teacher education program at UOIT, located in the Greater Toronto Area in Ontario, Canada. The associate teacher selection process at UOIT's Faculty of Education is typical of many other Ontario Faculties of Education, where requests are put forth to local school boards. Depending on the school administrators, principals might either individually ask or assign classroom teachers to host teacher candidates, or delegate the responsibility of finding associate teachers to the school department/division chairpersons, or principals might just make a school-wide call for any willing classroom teachers to act as associate teachers.

To obtain and maximize a wide variety of participants reflecting the associate teacher population from which the most can be learned, participant selection occurred through maximum variation purposive sampling (Merriam, 1998). Simple random sampling of the group of associate teachers within the two largest partnered local school boards occurred. Of the 91 invited associate teachers, 23 associate teachers initially agreed to use the ATLT and submitted consent forms to participate, and, eventually, only 17 of the 23 associate teachers participated in the study.

Collectively, the group of participants had 2-28 years teaching experience, taught Kindergarten to grade 6 , and had held various roles in previous teaching experiences, including self-contained special education classes, board consultant positions, and teaching in the intermediate (i.e., grades 7 and 8) divisions. They had acted as associate teachers 0-26 previous times, including three associate teachers who were first-time/new associate teachers, and five associate teachers who had never worked with UOIT.

\section{Data Collection}

Upon logging onto the ATLT with a unique researcher-generated AT user name and password, data collection immediately began via an internal tracking system designed specifically to track or record individual user information during a nine-week period. The ATLT automatic usergenerated numerical and narrative/text-based data included the following: 1) dates/times of use; 2) pages/sections accessed; 3) total times for page/section use; 4) confirmation of interactivity with activities (self-assessment type of tasks); and 5) open-ended, text-based responses (only if the AT chose to submit text-based responses).

\section{Data Analysis}

The quantitative and qualitative analyses encompassed 56 pages of raw ATLT user generated data, comprised of 15 pages of text-based responses and 1366 lines of numerical data.

Frequencies and related central tendencies (i.e., mean, minimum, maximum, median, sums) for ATLT page and section hits, number of log on instances, interactions with the self-assessment activities, text submissions, and total times spent per page and section were calculated. Additional statistical analyses for dispersion included measurement of the standard deviation page/section hits/times, interactions with the self-assessment activities, the minimum/maximum and range of times spent per page/section, and dates/times of use.

Text-based responses to open-ended questions inviting AT input regarding content/conceptspecific ideas occurred only if the Associate teachers volunteered to do so. Initially, descriptive and interpretive coding (Miles \& Huberman, 1994) of the text-based responses emerged in a relatively inductive manner; however, the ideas for marking portions of text stemmed from the study's underlying conceptual constructs (Miles \& Huberman, 1994). Using pattern-coding (Miles \& Huberman, 1994), initial descriptive and interpretive codes were collapsed into broader categories through exploring topics of convergence and divergence (Patton, 2002). Cognitive mapping of the concepts, allowed many deconstructed constructs to reorganize into a smaller 
number of key themes. In addition, Weft QDA (Fenton, 2006) facilitated the data reduction process. Lastly, to enhance the reliability of data coding, a colleague/academic researcher examined the codes and the data for consistency and fit.

\section{Findings}

The first section presents the quantitative findings surrounding how associate teachers used the ATLT (i.e., dates/times of use, pages accessed, length of time on pages, and number of interactions with activities), while the subsequent section explores the qualitative findings regarding how associate teachers responded to the open-ended (text-based response) reflective activities in the ATLT.

\section{Dates and Times of Use}

The 17 ATLT user participants logged on and interacted with the ATLT for a collective total of 1281 minutes. The mean ATLT use time was 99 minutes, the median ATLT use time was 109 minutes, and the minimum and maximum ATLT use time was 21 minutes and 161minutes respectively, with a standard deviation of 41 minutes. ATLT access during the field experience occurred throughout the nine-week access period. Table 1 displays the number of individual and cumulative associate teacher user sessions during the various stages of the nine-week ATLT access period.

\begin{tabular}{|c|c|c|c|c|c|c|c|}
\hline AT ID & $\begin{array}{c}\text { Total } \\
\text { number } \\
\text { of ses- } \\
\text { sions }\end{array}$ & $\begin{array}{c}\text { Before TC } \\
\text { arrival } \\
\text { (1 week) }\end{array}$ & $\begin{array}{c}\text { Field Ex- } \\
\text { perience - } \\
\text { Week } 1 \\
(1 \text { week) }\end{array}$ & $\begin{array}{l}\text { TCs re- } \\
\text { turn to } \\
\text { campus } \\
\text { (4 weeks) }\end{array}$ & $\begin{array}{c}\text { Field Ex- } \\
\text { perience } \\
\text { Block - } \\
\text { Week } 2 \\
\text { (1 week) }\end{array}$ & $\begin{array}{c}\text { Field Ex- } \\
\text { perience } \\
\text { Block - } \\
\text { Week } 3 \\
\text { (1 week) }\end{array}$ & $\begin{array}{c}\text { Field Ex- } \\
\text { perience } \\
\text { Block - } \\
\text { Week } 4 \\
\text { (1 week) }\end{array}$ \\
\hline AT1 & 1 & & & & & 1 & \\
\hline AT2 & 5 & & 1 & 2 & & 1 & 1 \\
\hline AT4 & 1 & & & & 1 & & \\
\hline AT7 & 2 & & 1 & 1 & & & \\
\hline AT8 & 1 & 1 & & & & & \\
\hline AT10 & 2 & 1 & & & & & 1 \\
\hline AT11 & 5 & 1 & & & 3 & 1 & \\
\hline AT13 & 2 & & & & 1 & 1 & \\
\hline AT15 & 7 & 1 & 1 & & 2 & 2 & 1 \\
\hline AT16 & 2 & & & & 1 & & 1 \\
\hline AT12 & 2 & & & 1 & & & 1 \\
\hline AT9 & 2 & & & & 2 & & \\
\hline AT17 & 4 & & & 2 & 1 & & 1 \\
\hline AT14 & 6 & & 1 & & 1 & 4 & \\
\hline AT3 & 1 & 1 & & & & & \\
\hline AT6 & 1 & & & 1 & & & \\
\hline AT5 & 2 & & 1 & & 1 & & \\
\hline Totals & 46 & 5 & 5 & 7 & 13 & 10 & 6 \\
\hline
\end{tabular}


ATLT access times also varied around the 24 clock throughout the nine-week period, as seen in Figure 5, which displays the hourly breakdown of login frequencies in ascending order. The ATLT tracking system registered the greatest number of logins from 13 out of the 17 Associate teachers in the evening, comprising $47.9 \%$ of the total number of logins.

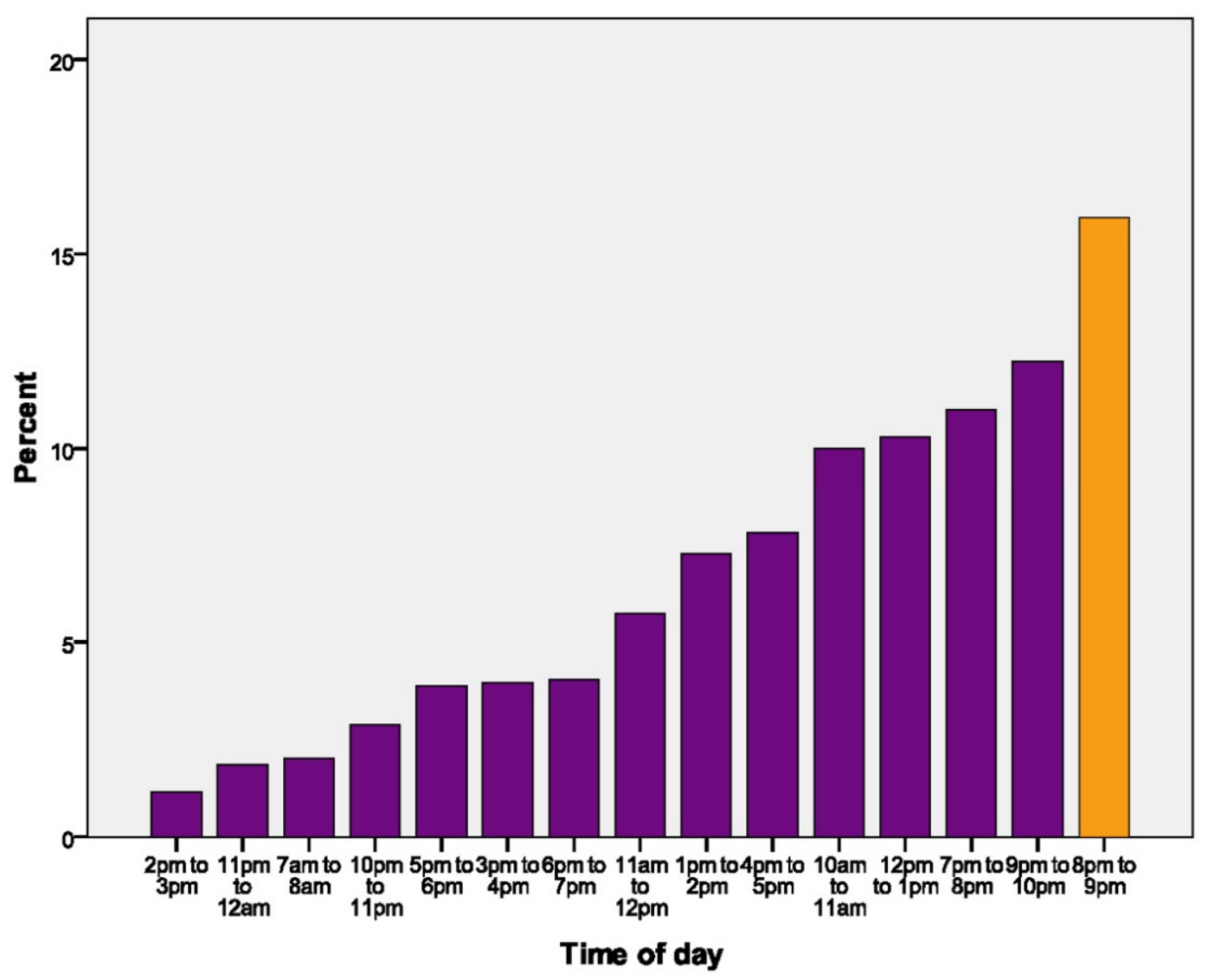

Figure 5: Hourly breakdown of login frequencies

\section{Pages and Sections Accessed}

The ATLT tracking system recorded 1292 'hits' or accessed pages. The section most accessed, with 316 visits, was the feedback section, and the least accessed session (after the site map and credits) was the AT role section. Figure 6 presents a summary of the number of visits for each of the ATLT sections. As previously mentioned, the ATLT tracking system recorded a total of 1281 minutes of ATLT use time by the 17 participants. Associate teachers spent the greatest amount of time on the planning section of the ATLT, logging a total of 352 minutes and after excluding the sitemap, credits, and home sections, the least amount of time was spent on the praxis section for a total time of 120 minutes. Figure 7 presents collective AT summaries of total times spent within each of the ATLT sections. 


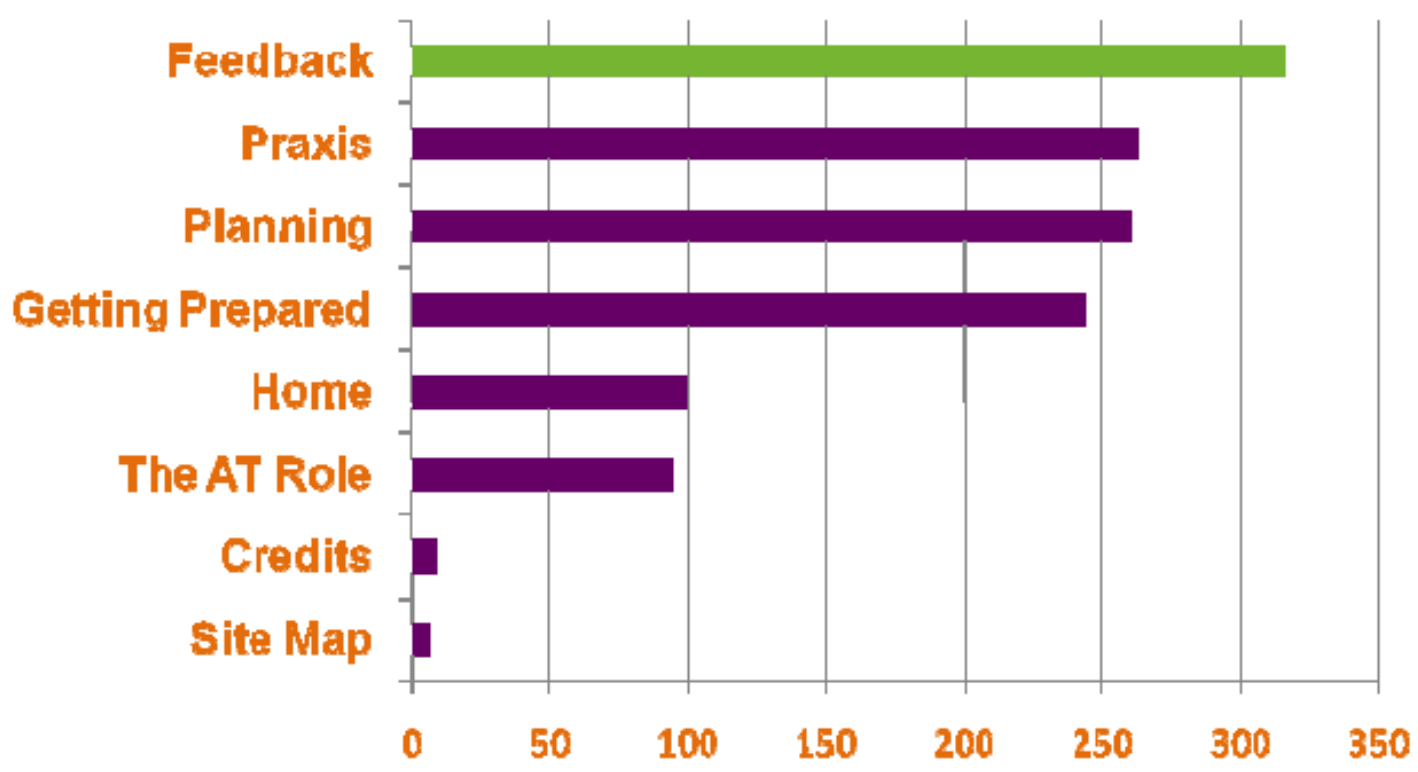

Figure 6: Number of hits per section of the ATLT

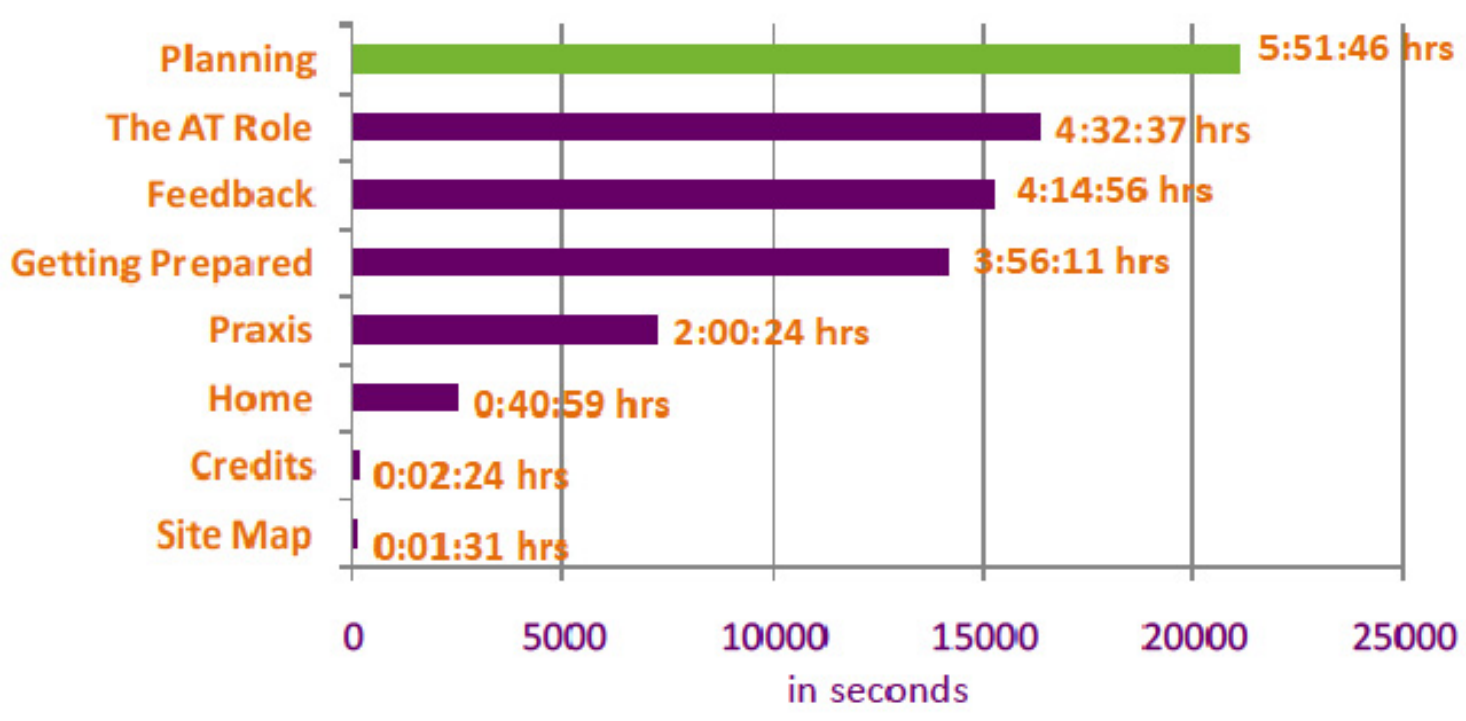

Figure 7: ATLT section times

\section{Interactive Activities}

The ATLT contained a variety of interactivity, such as rollover instructions and graphics, animated text/graphics, videos, hypermedia, as well as 22 opportunities that allowed the user to respond to one of the following three types of interactive activities: 1) application-based activities; 2) background knowledge text-based response activities; and 3) reflective text-based response activities. Table 2 displays the 22 individual interactive components categorized by one of the three types of above-mentioned interactivity, including descriptions and examples of each, as well as the total number of Associate teachers who interacted with the activity. 


\begin{tabular}{|l|l|l|l|l|}
\hline \multicolumn{5}{|c|}{ Table 2: Interactive activities on the ATLT } \\
\hline $\begin{array}{l}\text { Type of } \\
\text { Interactive } \\
\text { Activity }\end{array}$ & Description (examples) & $\begin{array}{l}\text { Section of } \\
\text { ATLT* } \\
\text { (quantity) }\end{array}$ & $\begin{array}{l}\text { Total } \\
\text { within } \\
\text { ATLT }\end{array}$ & $\begin{array}{l}\text { Number } \\
\text { of ATs ** }\end{array}$ \\
\hline $\begin{array}{l}\text { Application- } \\
\text { based activities }\end{array}$ & $\begin{array}{l}\text { contextualizes learning, makes meaning relevant, } \\
\text { and provides feedback to the users (Ally, 2004b) } \\
\text { (e.g., self-assessment such as click and check, drag } \\
\text { and drop, open-ended text based response) }\end{array}$ & $\begin{array}{l}\text { FB (2) } \\
\text { PLN (6) } \\
\text { GP (4) }\end{array}$ & 12 & 17 \\
\hline $\begin{array}{l}\text { Background } \\
\text { knowledge text- } \\
\text { based response } \\
\text { activities }\end{array}$ & $\begin{array}{l}\text { accesses user's prior knowledge (Piaget, 1950), fo- } \\
\text { cuses learner, allows for opportunity to consider the } \\
\text { context prior to the learning activity (e.g., How do } \\
\text { you prepare for a TC? Why is feedback important?) }\end{array}$ & $\begin{array}{l}\text { FB (1) } \\
\text { GP (1) }\end{array}$ & 2 & 15 \\
\hline $\begin{array}{l}\text { Reflective text- } \\
\text { based response } \\
\text { activities }\end{array}$ & $\begin{array}{l}\text { provides users opportunities to formally reflect and } \\
\text { comment on topics; embeds questions on content for } \\
\text { users to internalize; encourages learners to process } \\
\text { and reflect in relevant contexts (Ally, 2004b) (e.g., }\end{array}$ & $\begin{array}{l}\text { FB (3) } \\
\text { ATR (3) } \\
\text { Do you agree/disagree? Why? What do you think } \\
\text { about what you just viewed? Why is this important?) }\end{array}$ & $\begin{array}{l}\text { PX (1) } \\
\text { Fow }\end{array}$ & 15 \\
\hline $\begin{array}{l}* \text { FB - Feedback; PLN - Planning; GP - Getting Prepared; ATR - AT Role; PX - Praxis } \\
* * \text { Number of Associate Teachers (ATs) who responded to at least one activity of this type (out of 17) }\end{array}$ \\
\hline
\end{tabular}

\section{Responses to Reflective Activities}

Fifteen of the 17 Associate teachers responded to at least one of the eight text-based open-ended learning interactions (in the "feedback", "AT role", and "praxis" sections) which encouraged reflective practice in response to personal meanings and additional insights evoked by the ATLT content. After interacting with various components of the ATLT (e.g., viewing associate teacher/ teacher candidate testimonials, viewing vignettes of associate teacher/ teacher candidate interactions, reading text, considering quotes and images), the open-ended reflective types of questions solicited text-based responses from the associate teachers, regarding their perspectives, additional ideas, questions, surprises, and any insights regarding a topic within the aforementioned sections. All associate teachers who responded to these questions contributed multiple opinions and perspectives regarding a range of topics, not necessarily specific to the particular section of the ATLT where the reflective type of question was located. Given the reflective and open-ended nature of the questions, the 31 collective responses from the three sections overlapped considerably, resulting in several emerging themes surrounding the AT role. While the associate teachers' wide array of responses reflected the multifaceted role of the AT, their reflective responses revealed that they felt the top two aspects of the AT role included providing feedback to the teacher candidate and modeling. Table 3 summarizes the top five themes emerging through the reflective comments. 
Table 3: Associate Teachers' Perceptions of the AT Role

\begin{tabular}{|c|c|c|}
\hline Theme & $\begin{array}{l}\text { Number of } \\
\text { times } \\
\text { addressed* }\end{array}$ & Examples of Submitted Text \\
\hline AT as a provider of feedback & 27 & $\begin{array}{l}\text { ATLT_text_FB7 [1867-2178] I also believe that con- } \\
\text { structive feedback with the needs of the candidate in } \\
\text { mind are essential to a positive learning experience. Fur- } \\
\text { thermore, a discussion format acknowledges the skills, } \\
\text { opinions and knowledge the candidate possesses and al- } \\
\text { lows them to become active participants in their learning } \\
\text { experience. }\end{array}$ \\
\hline $\begin{array}{l}\text { AT as a model (i.e., daily aspects, } \\
\text { planning, instruction, reflection, } \\
\text { class management, organization, } \\
\text { best practices, complexities, posi- } \\
\text { tivity, content, lifelong learning, } \\
\text { professionalism) }\end{array}$ & 15 & $\begin{array}{l}\text { ATLT_text_PX_10 [194-412] They get to see how a } \\
\text { teacher forms his/her class - routines, rules, etc. from the } \\
\text { ground up. This is invaluable. }\end{array}$ \\
\hline $\begin{array}{l}\text { AT as a creator of safe learning } \\
\text { environments for TC }\end{array}$ & 11 & $\begin{array}{l}\text { ATLT_text_AT3 [3325-3529] Lastly, I think being sup- } \\
\text { portive of risk taking. It is a risk everytime they teach, it } \\
\text { is new territory, not every lesson will be perfect but there } \\
\text { will be positives and it is our role to build on those. }\end{array}$ \\
\hline $\begin{array}{l}\text { AT role serves as professional de- } \\
\text { velopment }\end{array}$ & 7 & $\begin{array}{l}\text { ATLT_text_FB9 [2436-2574] - I hope the experience my } \\
\text { TC has in my class is positive and a chance for growth } \\
\text { not just for themselves but also for myself as a teacher. }\end{array}$ \\
\hline AT role as influential & 7 & $\begin{array}{l}\text { ATLT_text_AT1 [18-427] Sometimes it is easy for an } \\
\text { associate teacher to forget what a large influence he/she } \\
\text { could play in making the field placement a complete suc- } \\
\text { cess for the teacher candidate. }\end{array}$ \\
\hline
\end{tabular}

\section{Discussion}

This paper explored a new and unique web-based form of learning/professional development for associate teachers. Specifically, this paper explored how associate teachers accessed and engaged with the ATLT with respect to dates/times of use, pages accessed, length of time on pages, and interaction with activities. These findings are now discussed.

\section{Associate Teachers' Use of the ATLT}

\section{Times, dates, location varied}

Data collected from the ATLT's internal tracking system revealed that associate teachers' accessed and interacted with the ATLT at various times, dates, and locations throughout the field experience. Although no known literature documenting how associate teachers interact with a WBLT created specifically to support the AT in implementing the role exists, the manner in which associate teachers used the ATLT is consistent with the WBLT literature. This diversity of use is important as it supports and reflects the notion that WBLTs are flexible, convenient learning tools, accessible to learners from any location with Internet availability (Downes, 2004). Presumably, associate teachers accessed the ATLT from various locations, evidenced by the diver- 
sity of log in times. For example, while some associate teachers logged on to the ATLT at various points throughout morning and afternoon periods during the school day (most likely from a school-based location), the most popular ATLT access time, occurred in the evenings, especially between 8:00 pm and 9:00 pm, where associate teachers accessed the ATLT most probably from a non-school location such as their homes.

Associate teachers also demonstrated great diversity in ATLT use throughout the nine-week ATLT access period. As seen in the usage dates, the ATLT-log in dates increased noticeably at the point in time when the teacher candidates returned to the classrooms for the three-week practicum block, to assume gradual and increased responsibility for the class. This usage reflects the nature of "just-in-time learning" (Ally, 2004a, p. 88) described as one of several instructional needs WBLTs might tackle in the workplace. Ally (2004a) suggested that employees in workplace settings use WBLTs to address a variety of instructional needs such as "learning remediation, just-in-time learning, job aids, and enrichment" (p. 88). The just-in-time use of the ATLT was also consistent with findings from AT literature, where Kent (2001) suggested that AT training occur as close as possible to the time of the field experience. Further to this, associate teachers indicated they preferred training and supports typically on an as needed basis (Kent, 2001; Ramanathan \& Wilkins-Canter, 1997). These findings reflect the flexible, accessible, and convenient nature of learning tools on the Internet. "For learners, online learning knows no time zones, and location and distance are not an issue. In asynchronous online learning, students can access the online materials at anytime" (Ally, 2004b, p. 5).

From a Technology Acceptance Model (Davis, 1985, 1989, Venkatesh \& Davis, 2000) perspective, the increase of ATLT use just before the practicum block might have also reflected the associate teachers' perceived usefulness of the ATLT as a tool to help them implement the associate teacher role. Based on the model, one might speculate that the perceived usefulness might have influenced the intention of the users (i.e., associate teachers), which in turn would could have resulted in the technology's (i.e., ATLT's) use (Venkatesh \& Davis, 2000).

\section{Planning and feedback sections accessed the most}

Keeping with the constructs that guided the development of the learning tool, the ATLT allowed associate teachers to access pages/sections in any given manner decided by the user. An interesting commonality and outcome that emerged from the pages and sections visited is that, collectively, the users gravitated towards the planning and feedback sections the most. This is hopeful in that a large body of related field experience literature informed the ATLT content. Specifically, content related to recommendations to improve the AT role via increased observation and feedback (Borko \& Mayfield, 1995), as well as the provision of increased support and guidance to teacher candidates regarding how to connect theory and practice (Beck \& Kosnik, 2000; Borko \& Mayfield, 1995).

If viewed from the TAM perspective, the model might suggest that associate teachers may have perceived these particular sections in the web-based learning tool to be useful and, as such, frequented those relevant sections. The converse might also be true, whereby, associate teachers may have perceived the remaining three sections of the learning tool not as useful, resulting in less access in comparison to the planning and feedback sections. Another possible explanation might be that the three less visited sections may have been more challenging to use, which, based on TAM, might influence the perceived usefulness of the tool overall. This seems unlikely, however, since the layout, navigation, and interactive activities were somewhat consistent throughout the ATLT sections. 


\section{Responses to reflective activities}

As previously mentioned, the reflective open-ended text-based questions solicited perspectives, additional ideas, questions, surprises, or insights from associate teachers regarding various topics related to the associate teacher role, feedback, and assisting the teacher candidate apply theory to practice. What is encouraging and interesting about the associate teachers' responses is that the associate teachers' descriptions of the role reflected findings from previous studies (Boudreau, 1999; Sanders et al., 2005; Weasmer \& Woods, 2003) and served as a framework for the ideal field experience, described by Darling-Hammond et al. (2005) as critical to the AT role. This is also promising in that associate teacher literature recommended associate teachers provide increased feedback (Borko \& Mayfield, 1995), provide support and guidance regarding planning and instruction (Beck \& Kosnik, 2000; Borko \& Mayfield,1995), collaborate, establish more personal connections, offer more emotional support, and allow teacher candidates more opportunities to observe (Beck \& Kosnik, 2000).

Based only on the text submissions entered onto the ATLT, it is difficult to determine whether associate teachers actually believed, reflected, or acquired their perspectives regarding their role through engaging with the ATLT. Associate teachers may have been simply restating what they viewed and/or heard via the ATLT or stating previously held perspectives. Based only on the text-based responses, no assumptions can be made regarding the extent of the associate teacher learning or practices. It is somewhat promising, though, that associate teachers at least considered and identified some of the ATLT content regarding important characteristics of the associate teacher role.

Given the busy nature of associate teachers, it was also surprising that the majority of associate teachers (15/17) actually responded to the open-ended (text-based response) interactive activities in the ATLT. Again, a lack of research documenting associate teacher participation with webbased learning tools exists; however, there does exist literature regarding practices in providing learning opportunities for web-based learners. As such, the underlying and inter-related constructs that framed the ATLT might serve as a potential explanation for the associate teachers' interactivity with the ATLT. The researcher made a steadfast effort to implement constructs, such as the inclusion of relevant learning experiences within real-world contexts, derived from the reflection and constructivist learning based literature (Anderson \& Elloumi, 2004). For example, the ATLT presented scenarios, topics, questions, and problems that experienced associate teachers might have previously encountered or inexperienced associate teachers might face in the future. As such, the planning of the learning interactions for the ATLT embedded reflective questions throughout (Ally, 2004b), based on real-life contextual issues associate teachers may face, perhaps provided associate teachers with opportunities for "turning a subject over in the mind and giving it serious and consecutive consideration" (Dewey, 1933, p. 3). By providing associate teachers with such reflective opportunities, they had opportunities for reflection on their own practice and perhaps faced their own unique problematic situations lying outside the realm of technical rationality (Schön, 1987) related to the role of the associate teacher, teacher candidate, and field experiences in general.

Once again, TAM might serve as a useful framework to consider why these associate teachers responded to the reflective text-based questions embedded within the ATLT. As Schön (1987) described, reflexivity guides the growth of professional practitioners such as teachers, and, if teachers' pre-service education experiences stressed reflective practice, then perhaps the associate teachers perceived the reflective activities, embedded in the technology, to be useful. This supposition is purely theoretical, using TAM's constructs as a guide, and further exploration would be required. 


\section{Conclusions - There is Potential...}

This paper, explored how associate teachers accessed and engaged with a web-based learning tool created specifically to support them as a tool for learning and professional development. Based on the findings revealed in this paper, it is evident that there is potential for a web-based form of learning or professional development such as the ATLT, created within a reflexive and constructivist framework, to serve as a flexible form of learning for associate teachers.

At the most basic level, it is first hopeful that a small group of associate teachers demonstrated that they would indeed log on, access, and interact with a variety of activities within the ATLT. This was reassuring in that busy schoolteachers have little spare time and already devote precious time to actually hosting and working with teacher candidates for little (if any) remuneration. The diverse nature of how associate teachers accessed and engaged with the ATLT is extremely optimistic in that many of these busy individuals took the time to access various areas of the ATLT, as they desired, and the majority of them even took time to reflect formally via open-ended questions regarding topics on the ATLT. Using the Technology Acceptance Model as a framework, perhaps associate teacher acceptance and interaction with the technology was influenced by the ATLT's perceived usefulness and perceived ease of use. Alternatively, perhaps, the nature of the associate teachers who volunteered for this particular study may be unique in that they willingly participated in this study where a good majority of invited associate teachers did not.

Although this paper did not explore the actual application of any learning constructed through accessing and interacting with the ATLT, the findings are hopeful based on the usage patterns and emerging themes within the associate teachers' reflective responses regarding the importance of the AT role - topics that were also prominently featured on the ATLT. Future research regarding the application of what associate teachers' perceived to be critical as they implement the role, would benefit this body of work, as well as future versions of the ATLT.

This work demonstrates that there exists the potential for a web-based learning tool to serve as a flexible form of learning or professional development; however, those who plan and create such professional development opportunities must carefully consider bodies of literature related to web-based learning tools, learning theory, and discipline-specific research. For example, rather than presenting pages of endless text-based content regarding best associate teacher practices, the content and delivery must reflect the theoretical constructs and discipline-specific research, rather than solely basing the learning tool on the author's or a group of administrators' own personal perspectives or experiences. By carefully and intentionally considering the body of work surrounding field experiences, associate teachers, teacher candidates, web-based learning tools, constructivist learning theory, and reflective practice, this paper explored how the merging of research might result in a flexible and alternative form of professional development. This paper addresses the provision of web-based learning to a very specific group of users; however, this work might benefit other professionally based higher education programs with required practicum components and rely on external partners of the community to work with students.

From an ease of use perspective, Gong, $\mathrm{Xu}$, and $\mathrm{Yu}$ (2004) concluded in their work with schoolteachers, "in order to facilitate teachers' IT acceptance, it is critical to increase their perceived usefulness and perceived ease of use simultaneously" (p. 371). They recommended the implementation of "proactive" (p.371) measures to help teachers be made aware of a system's useful features, as well as a user-friendly interface, to enhance teachers' perceived ease of use.

In addition, by carefully and intentionally considering issues such as lack of resources (i.e., time, finances, and human resources) (Beck \& Kosnik, 2000; Coulon, 2000; Hastings \& Squire, 2002; Kahn, 2001; Kent, 2001; Ramanathan, \& Wilkins-Canter, 1997; Veenman, Denessen, Gerrits, \& Kenter, 2001) that often prevented the implementation of supports for associate teachers, this paper demonstrated how a flexible, accessible, and convenient program of learning might address 
and overcome some of these preventative factors. It is important to note, however, that although a web-based form of learning might address resource-based deterrents, as previously mentioned, associate teacher willingness or unwillingness to access the learning tool is still the inherent challenge and implication for practice for those who organize practica.

Pre-service teacher education programs, or any other higher education organization offering professional programs with practicum components, must not assume that all associate teachers or other community-based partners will respond in this manner, especially when many of such partners already volunteer their time to host our higher education students. Given the drawback of "time" documented in the literature, getting associate teachers to log on and use the learning tool could be quite challenging and limit the learning potential of the ATLT. Perhaps future research to investigate ATLT users' acceptance and use of the tool could include formal TAM (or its derivatives) metrics to explore more deeply ATLT users' perceptions of the tool's usefulness, ease of use, and other constructs such as the role of experience (Venkatesh \& Bala, 2008) in acceptance and use of the new technology. On the other hand, perhaps the documented unwillingness reflects broader underlying assumptions about the nature and importance of the associate teacher role.

Future research must now move beyond the exploratory and examine more specifically, and with a larger sample size, participants' actual application of learning constructed via the web-based learning experience within the practicum setting. Will associate teachers reflect on their practice, and host the practicum experience in a manner that manifests sound research-based practice? How do our higher education students who spend time in the field with our community members benefit from their mentors' web-based learning? In addition, how might other members of the field experience, specifically teacher candidates and faculty, access and interact with the learning tool? Adjustments to the learning tool to accommodate the new users would be required; however, it might add to the richness of the tool and the research. These are certainly areas for future consideration and research; however, for now, this paper's findings, although preliminary in nature, might provide resource-strapped higher education organizations with alternative web-based strategies to support their community-based partners. Professionals in the community, who often volunteer a good deal of time to work with students and may or may not receive a small stipend or honorarium as remuneration, are critical and central to the successful implementation of the required practicum components of many higher education programs. A web-based form of professional development grounded in reflective practice and constructivist learning theory may not only guide the "artistry" of our partner professional practitioners during practicum, but ideally, such professional development may enhance the practicum experience to optimize learning for those future professionals with whom our partners work.

\section{References}

Agostinho, S., Bennett, S., Lockyer, L., \& Harper, B. (2004). Developing a learning object metadata application profile based on LOM suitable for the Australian higher education market. Australasian Journal of Educational Technology, 20(2), 191-208.

Allen, M. A. (2003). Eight research questions on teacher preparation: What does the research say? Denver, CO: Education Commission of the States.

Ally, M. (2004a). Designing effective learning objects. In R. McGreal (Ed.), Online education using learning objects (pp. 87-97). New York, NY: Routledge Falmer.

Ally, M. (2004b). Foundations of educational theory for online learning. In T. Anderson \& F. Elloumi (Eds.), Theory and practice of online learning (pp. 3-33). Athabasca, AB: Athabasca University.

American Federation of Teachers. (2000). Building a profession: Strengthening teacher preparation and induction, Report of K-16 Teacher Education Task Force. Washington, DC: Author. 
Anderson, T., \& Elloumi, F. (2004). Introduction. In T. Anderson \& F. Elloumi (Eds.), Theory and practice of online learning (pp. xiii - xxiv). Athabasca, AB: Athabasca University.

Beck, C., \& Kosnik, C. (2000). Associate teachers in pre-service education: Clarifying and enhancing their role. Journal of Education for Teaching, 26(3), 207-224.

Beck, C., \& Kosnik, C. (2002). Components of a good practicum placement: Student teacher perceptions. Teacher Education Quarterly, 29(2), 81-98.

Borko, H., \& Mayfield, V. (1995). The roles of cooperating teacher and university supervisor in learning to teach. Teaching and Teacher Education, 11(5), 501-518.

Boudreau, P. (1999). The supervision of a student teacher as defined by cooperating teachers. Canadian Journal of Education, 24(4), 454-461.

Butson, R. (2003). Learning objects: Weapons of mass instruction. British Journal of Educational Technology, 34(5), 667-669.

Chuttur, M. Y. (2009). Overview of the technology acceptance model: Origins, developments and future directions. Sprouts: Working Papers on Information Systems, 9(37), 9-37.

Creswell, J. W. (2004). Educational research: Planning, conducting, and evaluating quantitative and qualitative research (2nd ed.). Upper Saddle River, NJ: Pearson Education.

Crocker, R. K., \& Dibbon, D. C. (2008). Teacher education in Canada. Kelowna, BC: Society for the Advancement of Excellence in Education (SAEE).

Coulon, S. C. (2000). The effects of self-instructional modules on the task statements of cooperating teachers. Education Canada, 111(3), 325-338.

Darling-Hammond, L. (2006). Powerful teacher education: Lessons from exemplary programs. San Francisco, CA: Jossey-Bass.

Darling-Hammond, L., \& Baratz-Snowden, J. (2007). A good teacher in every classroom: Preparing the highly qualified teachers our children deserve. Educational Horizons, 85(2), 111-132.

Darling-Hammond, L., Hammerness, K., Grossman, P., Rust, F., \& Shulman, L. (2005). The design of teacher education programs. In L. Darling-Hammond \& J. Bransford (Eds.), Preparing teachers for a changing world (pp.390-441). San Francisco, CA: Jossey-Bass.

Davis, F. D. (1985). A technology acceptance model for empirically testing new end-user information systems: Theory and results (Unpublished doctoral dissertation). MIT Sloan School of Management, Cambridge, MA.

Davis, F. (1989). Perceived usefulness, perceived ease of use, and user acceptance of information technology. MIS Quarterly, 13(3), 319-40.

Dewey, J. (1916). Democracy in education. New York, NY: Macmillan Publishing Company.

Dewey, J. (1933). How we think. Boston, MA: Houghton Mifflin Company.

Downes, S. (2004). Learning objects: Resources for learning worldwide. In R. McGreal (Ed.), Online education using learning objects (pp. 21-31). New York, NY: Routledge Falmer.

Duquette, C. (1998). Perceptions of mentor teachers in school-based teacher education programs. Journal of Education for Teaching, 24(2), 177-179.

Fenton, A. (2006). Weft QDA [Computer software]. Retrieved on July 23, 2009 from http://www.pressure.to/qda/

Fosnot, C. T. (2005). Preface. In C. T. Fosnot (Ed.), Constructivism: Theory, perspectives, and practice (2nd ed.), (pp. ix - xii). New York, NY: Teachers College Press.

Giebelhaus, C. R., \& Bowman, C. L. (2002). Teaching mentors: Is it worth the effort? The Journal of Educational Research, 95(4), 246-254. 
Gong, M., Xu, Y., \& Yu, Y. (2004). An enhanced technology acceptance model for web-based learning. Journal of Information Systems Education, 15(4), 365-374.

Hastings, W., \& Squires, D. (2002). Restructuring and reculturing: Practicum supervision as professional development for teachers. Asia-Pacific Journal of Teacher Education, 30, 79-91.

Hobson, J. H. (2002). Student teachers' perceptions of school-based mentoring in initial teacher training (ITT). Mentoring \& Tutoring, 10(1), 5-20.

Johnson, R. B., \& Onwuegbuzie, A. J. (2004). Mixed methods research: A research paradigm whose time has come. Educational Researcher, 33(7), 14-26.

Jonassen, D. H., Hernandez-Serrano, J., \& Choi, I. (2000). Integrating constructivism and learning. In J. Spector \& T. Anderson (Eds.), Integrated and holistic perspectives on learning, instruction and technology: Understanding complexity (pp. 103-128). Netherlands: Kluwer Academic Publishers.

Kahn, B. (2001). Portrait of success: Cooperating teachers and the student teaching experience. Action in Teacher Education, 22(4), 48-58.

Kay, R. H., \& Knaack, L. (2005). Developing learning objects for secondary school students: A multicomponent model. Interdisciplinary Journal of Knowledge and Learning Objects, 1, 229-254. Retrieved from http://www.ijello.org/Volume1/v1p229-254Kay_Knaack.pdf

Kay, R. H., Knaack, L., \& Petrarca, D. (2009). Exploring teacher perceptions of web-based learning tools. Interdisciplinary Journal of E-Learning and Learning Objects, 5, 27-50. Retrieved from http://ijklo.org/Volume5/IJELLOv5p027-050Kay649.pdf

Kent, S. I. (2001). Supervision of student teachers: Practices of cooperating teachers prepared in a clinical supervision course. Journal of Curriculum and Supervision, 16(3), 228-244.

Levine, A. (2006). Educating school teachers. Washington, DC: The Education Schools Project.

McGreal, R. (2004). Learning objects: A practical definition. International Journal of Instructional Technology and Distance Learning, 1(9), 21-32.

McIntyre, D. J., \& Killian, J. E. (1987). The influence of supervisory training for cooperating teachers on preservice teachers' development during early field experiences. Journal of Educational Research, $80(5), 277-282$.

Merriam, S. B. (1998). Qualitative research and case study applications in education, revised and expanded from case study research in education. San Francisco, CA: Jossey-Bass.

Miles, M. B., \& Huberman, A. M. (1994). Qualitative data analysis: An expanded sourcebook (2nd ed.). Thousand Oaks, CA: Sage.

National Commission on Teaching and America's Future. (1996). What matters most: Teaching for America's future. Washington, DC: Author.

Neuman, W. L. (2003). Social research methods. Qualitative and quantitative approaches. (5th ed.). Boston, MA: Pearson Education.

Parrish, P. E. (2004). The trouble with learning objects. Educational Technology Research \& Development, 52(1), 49-67.

Patton, M. Q. (2002). Qualitative research evaluation methods (3rd ed.). Thousand Oaks, CA: Sage Publications.

Phillips, D. C., \& Soltis, J. F. (2004). Perspectives on learning (4th ed.). New York, NY: Teacher's College Press.

Phye, G. D. (1997). Learning and remembering: The basis for personal knowledge construction. In G. D. Phye (Ed.), Handbook of academic learning: Construction of knowledge (pp. 47-64). San Diego, CA: Academic Press. 
Ramanathan, H., \& Wilkins-Canter, E. (1997, October). Training for cooperating teachers and university supervisors in their role as evaluators in early field experiences. Paper presented at the Annual Meeting of the Mid-Western Educational Research Association, Chicago, IL.

Rippon, J. H., \& Martin, M. (2006). What makes a good induction supporter? Teaching and Teacher Education, 22, 84-99.

Sanders, M. (2005). Effective mentoring of student teachers: A further contribution. New Zealand Journal of Teachers' Work, 2(2), 129-135.

Sanders, M., Dowson, M, \& Sinclair, C. (2005). What do associate teachers do anyway? A comparison of theoretical conceptualizations in the literature and observed practices in the field. Teachers College Record, 107(4), 706-738.

Schön, D. A. (1987). Educating the reflective practitioner: Toward a new design for teaching and learning in the professions. San Francisco, CA: Jossey-Bass.

Spector, J. (2000). Introduction. In J. Spector \& T. Anderson (Eds.), Integrated and holistic perspectives on learning, instruction and technology: Understanding complexity (pp. xi-xxii). Netherlands: Kluwer Academic Publishers.

Teddlie, C., \& Tashakkori, A. (2009). Mixed methods research: Integrating quantitative and qualitative approaches in the social and behavioural sciences. Thousand Oaks, CA: Sage Publications.

Veenman, S., Denessen, E., Gerrits, J., \& Kenter, J. (2001). Evaluation of a coaching programme for cooperating teachers. Educational Studies, 27(3), 317-340.

Venkatesh, V., \& Bala, H. (2008). Technology acceptance model 3 and a research agenda on interventions. Decision Sciences, 39(2), 273-315.

Venkatesh, V., \& Davis, F. D. (2000). A theoretical extension of the technology acceptance model: Four longitudinal field studies. Management Science, 46, 186-204.

Venkatesh, V., Morris, M. G., Davis, G. B., \& Davis, F. D. (2003). User acceptance of information technology: Toward a unified view. MIS Quarterly, 27, 425-478.

Volante, L. (2006). Essential elements in teacher education: Preservice student perspectives. Alberta Journal of Educational Research, 52(2), 167-180.

Weasmer, J., \& Woods, A. M. (2003). The role of the host teacher in the student teaching experience. Clearing House, 76(4), 174-177.

Wideen, M. F., \& Holborn, P. (1990). Teacher education in Canada: A research review. In R. P. Tisher \& M. F. Wideen (Eds.), Research in teacher education: International perspectives (pp. 11-32). London: Falmer Press.

Wiley, D. A. (2000). Connecting learning objects to instructional design theory: A definition, a metaphor, and a taxonomy. In D. A. Wiley (Ed.), The instructional use of learning objects: Online version. Retrieved April 25, 2006, from http://reusability.org/read/chapters/wiley.doc

Wiley, D. A., Waters, S., Dawson, D., Lambert, B., Barclay, M., \& Wade, D. (2004). Overcoming the limitations of learning objects. Journal of Educational Multimedia and Hypermedia, 13(4), 507-521.

Wilson, S. M., Floden, R. E., \& Ferrini-Mundy, J. (2001). Teacher preparation research: Current knowledge, gaps, and recommendations - A research report prepared for the U.S. Department of Education. Washington, DC: Center for the Study of Teaching and Policy.

Yin, R. K. (2003). Case study research: Design and methods (3rd ed.). Thousand Oaks, CA: Sage Publications. 


\section{Biography}

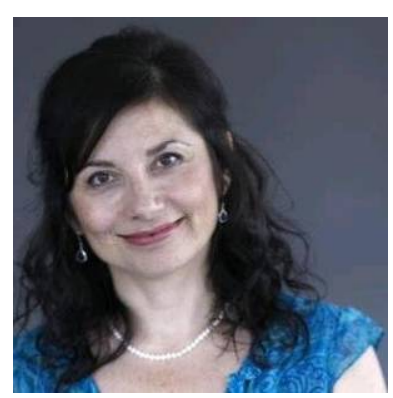

Dr. Diana Petrarca is a founding member of the Faculty of Education at UOIT, a southern Ontario university, which opened its doors to students in September 2003. Diana is currently an assistant professor at the Faculty of Education at UOIT, teaching in both Bachelor of Education and Masters programs. Her research interests include the preservice teacher education pedagogies, the practicum, associate teachers, and web-based learning. 